\title{
Percepção do Corpo, Medo da Morte, Religião e Doação de Órgãos
}

\author{
Pedro Fernando Bendassolli ${ }^{12}$ \\ Universidade Estadual Paulista, Assis
}

\begin{abstract}
Resumo
O objetivo desta pesquisa foi o de levantar as principais razões que levam estudantes universitários a doarem seus órgãos para transplante e as relações entre a doação de órgãos, o medo da morte e a religião dos participantes. Para tanto, foram realizados três estudos interdependentes, os quais somaram a participação de 192 estudantes de uma universidade pública do Estado de São Paulo. Os resultados obtidos nestes estudos sugerem, como sendo as principais razões para a doação: desejo de continuar a vida do outro; reaproveitamento dos órgãos; dar qualidade de vida aos que necessitam de um transplante; inutilidade do corpo após a morte. Quanto à não doação, as principais razões foram: crítica à lei dos transplantes; crítica ao sistema de saúde brasileiro; razões bioéticas, tais como receio de morte premeditada e contrabando de órgãos. Nestes estudos não foi encontrada relação significativa entre religião e doação de órgãos, mas foi encontrada entre o medo da morte e a não doação.

Palavras-chave: Doação de órgãos; transplantes; imagem corporal; morte; religião.
\end{abstract}

\section{Body Perception, Fear of Death, Religion and Organ Donation}

\begin{abstract}
The goal of this research study was to present some reasons for which academical students are considered donors or non-donors of their organs and the links among the organ donation, the fear of death and the participant's religion. Three interdependent studies were carried out, which considered altogether 192 academical students from a public university of São Paulo-State Brazil. The main reasons for donation were: the desire to go on living the other one's life; reusing of the organs; giving life quality to whom needs a transplant; uselessness of the body after death. As to the non-donation, the main reasons were: criticism to the law of transplants; criticism to the Brazilian health system ; bioethical reasons, such as fear of premeditated death and smuggling of organs. In those studies no significant relationship was found between religion and donation of organs, but it was found between fear of death and non-donation.

Keywords: Organ donation; transplants; corporal image; death; religion.
\end{abstract}

Principalmente a partir de 1997 houve, aqui no Brasil, uma intensificação do debate a respeito da doação de órgãos, o que envolveu pessoas e instituições das mais variadas áreas com o objetivo de promover uma reflexão, na saúde pública, na mídia, na legislação brasileira e nos diversos grupos sociais, sobre algumas de suas implicações, tais como a sua necessidade social, os critérios relativos aos procedimentos de transplantação de órgãos, a nova lei aprovada sobre o assunto, as "filas de espera", as dificuldades de se encontrar um doador, entre tantas outras questões. Associada à relevância social deste debate,

\footnotetext{
${ }^{1}$ Endereço para correspondência: Rua Campos Salles, 2494. Vila Independência. 13416-310 - Piracicaba - SP. Fone: (19) 433-2830. E-mail: pedrofb@uol.com.br

${ }^{2}$ Este artigo resultou de um projeto de Iniciação Científica do autor, que deseja registrar aqui seus mais sinceros agradecimentos ao Prof. José Sterza Justo pela orientação oferecida. Agradeço também aos Profs. José Luiz Guimarães e Fernando Frei, por seus comentários e observações. Por fim, agradeço o apoio da Fundação de Amparo à Pesquisa do Estado de São Paulo (FAPESP, processo 96/08919-6).
}

acreditamos que a Psicologia não possa estar ausente. Pelo contrário, nela repercutem muitos dos questionamentos oriundos da problematização social sobre a doação de órgãos. Neste caso, estamos diante de interrogações que penetram no campo da psicologia clínica da saúde, na psicologia social e até mesmo no campo da psicologia institucional, demandando um necessário equacionamento metodológico e prático para se promover um efetivo projeto de intervenção sobre o assunto destacado.

Este artigo é resultado de uma pesquisa realizada em três estudos interdependentes, desdobrados ao longo de quase três anos. O objetivo geral de todo o trabalho consistiu em levantar e investigar as possíveis razões que levariam estudantes universitários a serem doadores ou não doadores de seus órgãos para transplante. Todas as etapas da pesquisa foram executadas tendo como referência a mesma população de estudantes universitários, embora em cada estudo tenham sido selecionados participantes diferentes. Do ponto de vista teórico, foram considerados três principais grupos de argumentações. 
O primeiro diz respeito à associação existente entre a doação de órgãos e a percepção que o indivíduo tem de seu próprio corpo. $\mathrm{Na}$ literatura, não são raros os estudos que apontam para o fato de que a percepção do corpo pelo indivíduo, o modo como ele se identifica e se relaciona com sua imagem corporal, e o modo como os órgãos figuram nessa imagem, podem servir, quer como motivos de facilitação, ou como de resistência à doação (Belk, 1992).

A percepção que cada um tem de seu próprio corpo, ou do corpo de outra pessoa, envolve uma ampla série de componentes constitutivos. Esquematicamente, cito os seguintes: o conhecimento médico-científico (Certeau, 1990/1996; Sant'Anna, 1995a; Scavone, 1996) - que cria e permanentemente alimenta um tipo muito particular de corpo, cujas principais características são a sua fragmentação em "pedaços" ou "peças" permutáveis, como órgãos, tecidos, substâncias etc. (Braidotti, 1987; Le Breton, 1990; 1993/1995, Virilio, 1993/1996), e a sua "separação" do próprio homem, como se se tratasse de uma "máquina" ou de um "alter ego" dele (Le Breton, 1990) -; o sentimento de propriedade particular e inalienável do corpo por parte do indivíduo (Baudrillard, 1970; Corbin, 1987/1990; Sant'Anna, 1995b); os fatores psicológicos e inconscientes ligados à formação e manutenção da imagem corporal (Capisano, 1989; Leclaire, 1979/1992; Schilder, 1950/1981); a relação inconsciente existente entre o "eu" e o "corpo" (Aulagnier, 1979/1985; 1986/1990; 1991; Costa, 1986); e, finalmente, o narcisismo (Bleichmar, 1981/1985; Green, 1982/1988; 1995). Todos estes itens, que não estão isolados de um contexto sócio-histórico, ajudam a delimitar um quadro de referências para que possamos compreender a doação de órgãos a partir do campo social, psicológico e histórico que se tem instituído em relação ao corpo, e também para que possamos analisar como a doação contribui para uma reformulação ou manutenção da própria identidade pessoal, já que o corpo é a "a condição do homem, lugar de sua identidade" (Le Breton, 1990, p. 262).

Além da percepção do corpo, também se levou em conta que a maneira como a morte é tratada nos dias de hoje, em nossa cultura ocidental, pode funcionar como um potencial fator a influenciar a predisposição das pessoas relativamente à doação (favorável ou não favorável a ela). Estudos têm demonstrado que, quanto maior o medo da morte, maior parece ser a recusa pela doação de órgãos (Kopfman \& Smith, 1996; Shepherd \& Lefcourt, 1992; 1995). Ocorre que a doação de órgãos pode funcionar como um tipo de "imagem negativa" da morte: ela pode "evocar" esta última ou então pode "potencializá-la", sobretudo quando parece estar ligada à mutilação do corpo após a morte, ou seja, à retirada de um órgão exatamente num momento dolorido para a família que perdeu, por exemplo, um ente querido (René, Vieira, Daniels \& Santos, 1994). Por outro lado, em razão da grande valorização atual da vida (graças, em parte, ao seu prolongamento pela medicina e pela ciência em geral), a morte, entre nós do Ocidente, tem tido muito pouco espaço para uma reflexão profunda, para um enfrentamento indispensável (Ariès, 1977/1990; Kovács, 1992), restringindo-se a lugares devidamente instituídos para isso, como nos hospitais e clínicas especializadas (Le Breton, 1990; 1993/1995). A doação de órgãos poderia figurar, então, como uma vigorosa aliada desse desejo contemporâneo de levar a vida às últimas conseqüências, como se a morte pudesse ser evitada e o luto prorrogável até o limite das forças humanas, alimentando um tipo de desejo de "imortalidade” do próprio “eu” (Green, 1982/ 1988).

Por fim, o terceiro grupo de argumentações envolve os aspectos religiosos, os quais podem dificultar a doação de órgãos ao pôr no caminho crenças, convicções, superstições ou informações distorcidas a respeito dela (Kent \& Owens, 1995; Radecki \& Jaccard, 1997; Riether \& Mahler, 1995). Deu-se, também, atenção à suposta representação social da doação de órgãos (Moscovici, 1978; Souza Filho, 1995; Spink, 1995), verificando como ela é retratada culturalmente, quais características estão amiúde associadas a ela, como essas características se formaram e graças a quais conteúdos históricos, sociais e psicológicos. Enfim, procuramos analisar o tipo de representação social que possui a pessoa necessitada de um transplante, ou seja, como os participantes desta pesquisa vêem aqueles para os quais seus órgãos seriam eventualmente doados (os chamados "receptores"), observando se isso contribui, ou não, para a formação de suas respectivas opiniões sobre o assunto.

Os três Estudos a serem relatados abaixo partilham de uma mesma trajetória de investigações, embora cada um deles apresente objetivos e metodologias particulares. O Estudo 2 é uma continuidade do Estudo 1, porém, sobre um regime metodológico distinto. Já o Estudo 3 é um aprofundamento de algumas hipóteses levantadas principalmente no Estudo 1. Na seqüência serão apresentados, separadamente, cada um deles. Ao final será feita uma discussão geral dos resultados obtidos.

\section{Estudo 1}

O objetivo deste estudo foi levantar e identificar, através de um plano exploratório qualitativo, as razões que levariam alguns estudantes universitários a serem 
doadores, não doadores ou indecisos a respeito da doação de seus próprios órgãos para transplante. A intenção, aqui, foi estabelecer um primeiro contato com a problemática da doação de órgãos, restringindo um possível quadro de interpretações para o tema, a ser aprofundado em trabalhos posteriores (Estudos 2 e 3).

\section{Participantes}

\section{Método}

Foram selecionados 40 estudantes de graduação de uma universidade pública do Estado de São Paulo. A faixa de idade variou entre 22 e 27 anos e levou-se em consideração a seleção de ambos os sexos (no caso, foram escolhidos 20 homens e 20 mulheres).

\section{Elaboração e Aplicação dos Instrumentos}

Os dados foram coletados mediante a realização, com cada um dos participantes, de uma entrevista semiestruturada, que tomou como roteiro a seguinte questão: "Você se considera um doador, um não doador ou um indeciso a respeito da doação de seus próprios órgãos para transplante? Por quê?" A partir da resposta ao "por quê" da questão apresentada, o pesquisador seguiu dois procedimentos básicos: (1) fazia intervenções com o intuito de esclarecer pontos obscuros ou considerados superficiais na resposta do participante, permitindo, assim, que a coleta de dados pudesse ser o mais abrangente possível; (2) procurava explorar outros aspectos envolvidos com a problemática, mediante a utilização de um sistema de tópicos flexíveis quanto à ordem de abordagem. Esses tópicos foram elaborados com base no referencial teórico selecionado e refletem as hipóteses contidas nos objetivos específicos do trabalho. (Tabela 1)

Quando o participante considerava que não tinha nada mais a acrescentar o pesquisador então pedia para que ele fizesse uma síntese geral da conversa, integrando, dessa forma, os vários aspectos abordados, facilitando a coesão das informações fornecidas. Com a autorização do participante cada entrevista foi gravada e, posteriormente, transcrita na íntegra para análise. Além disso, o tempo médio de duração de cada uma delas foi de, aproximadamente, 30 minutos e se realizaram nas dependências do campus universitário, em local e horário previamente agendados.

Tabela 1. Sistemas de Tópicos que Nortearam a Entrevista Semi-Estruturada Realizada no Estudo 1

Tópico I. Relação com o corpo

Entre outros fatores, este tópico compreendeu aspectos relacionados à imagem corporal (o significado do corpo; a percepção que o sujeito tem dele; o simbolismo e a representação do corpo e de seus órgãos); ao narcisismo; à inviolabilidade do corpo; à posse pessoal do próprio corpo.

Tópico II. Mutilação do corpo após a morte

Aspectos que sinalizaram para o modo como o sujeito compreende a mutilação de seu corpo; a "perda" de determinados órgãos ou de todos eles; a idéia de como o corpo seria tratado, em função de ser um doador, após a morte.

Tópico III. Crenças, mitos e superstições

Disse respeito aos aspectos religiosos e supersticiosos que poderiam estar envolvidos quando da tomada de decisão por doar órgãos; sinalização dos valores religiosos na apreensão do corpo; influência da religião na formação do altruísmo para a doação.

Tópico IV. Percepção da morte

Aspectos que sinalizaram eventual medo e/ou negação da morte; a compreensão e vivência da morte de si próprio; imagem corporal e morte (a morte e a percepção/significação do corpo); a valorização contemporânea da vida; necessidade de prolongar a vida das pessoas.

Tópico V. Informações sobre a doação de órgãos

Aspectos que diziam respeito à nova lei sobre o assunto; sobre a necessidade social de se doar órgãos; sobre aspectos médicos da doação (tais como morte cerebral, a maneira de se retirar os órgãos; o Sistema Brasileiro de Saúde etc.); informações relativas à bioética dos transplantes. 


\section{Procedimentos de Análise dos Dados}

Neste Estudo submeteu-se todas as entrevistas realizadas e transcritas à análise de conteúdo (Bardin, 1977/1979; Grawitz \& Pinto, 1967; Souza Filho, 1995), que aqui consistiu numa classificação temática das razões pelas quais os participantes se consideravam doadores, não doadores ou indecisos sobre a doação de seus próprios órgãos para transplante. O critério de categorização (classificação) foi o semântico e, portanto, o agrupamento das unidades de sentido - dos temas foi feito por aproximação semântica. Em outras palavras, este é o critério de classificação por proximidade conceitual: as unidades de significação foram agrupadas juntamente com outras semelhantes para comporem categorias temáticas, de acordo com a orientação fornecida pela base teórica da pesquisa.

\section{Resultados}

Dos 40 entrevistados, 32 eram doadores (13 homens e 19 mulheres), sete eram indecisos (seis homens e uma mulher) e um era não doador (masculino) dos próprios órgãos. As razões fornecidas pelos participantes para justificar suas respectivas opções (doar, não doar ou ficar indeciso) foram categorizadas e quantificadas a partir da análise de conteúdo e expressas pela tabela abaixo (Tabela 2).
A seguir é descrita qualitativamente, o conteúdo de cada uma dessas categorias, procurando expor o que representam e do que são exatamente compostas. Para tanto, em cada uma delas apresentamos duas transcrições das entrevistas, ilustrando, dessa forma, o respectivo conteúdo da categoria.

\section{Corpo-matéria}

Esta categoria reúne os temas que se referem à percepção de que o corpo humano não se distingue em absolutamente nada do restante da natureza orgânica, sendo composto por órgãos e tecidos capazes de serem úteis para outros corpos assim que o organismo falecer. Este último não estaria mais associado ao indivíduo após a sua morte, nem associado à memória do familiar falecido, mas seria considerado como uma matéria orgânica como outra qualquer.

"No meu modo de ver, o corpo é matéria: morreu, é matéria que vai virar adubo. (...) é uma matéria como uma árvore, que pode ser utilizada para provocar a felicidade de outra pessoa" (P.19)

"O nosso corpo é como uma máquina. Sou um doador devido a encarar a vida da pessoa como sendo sua personalidade, sua maneira de se comportar, seus conceitos e

Tabela 2. Razões Apontadas pelos Participantes para serem Doadores, Não Dadores ou Indecisos a Respeito da Doação de seus Próprios Órgãos

\begin{tabular}{llccc}
\multirow{2}{*}{ Opção } & Categoria & \multicolumn{2}{c}{ Número de participantes* } \\
\cline { 3 - 4 } & & Masculino & Feminino & Total \\
\cline { 2 - 4 } Doador & Corpo-Matéria & $(n=20)$ & $(n=20)$ & $(N=40)$ \\
& Ajudar as pessoas & 13 & 17 & 30 \\
& Continuidade da vida do receptor & 13 & 29 \\
& Reaproveitamento dos órgãos & 11 & 11 & 22 \\
& Qualidade de vida ao receptor & 5 & 5 & 16 \\
& Necessidade social da doação & 7 & 2 & 9 \\
& Razões religiosas & 1 & 3 & 5 \\
\hline \multirow{2}{*}{ Indeciso } & Razões ligadas ao transplante & 5 & - & 3 \\
& Corpo-Pessoa & 2 & 1 & 2 \\
& Sistema Brasileiro de Saúde & 2 & - & 2 \\
\hline \multirow{2}{*}{ Não doador } & Legislação sobre doação de órgãos & 2 & - & 1 \\
\hline
\end{tabular}

(*) Categorias múltiplas 
suas idéias. E vejo o corpo apenas como algo que pode conter nosso interior: a alma, o espírito" (P.31)

\section{Ajudar as Pessoas}

Congrega todos os temas que dizem respeito ao desejo de ajudar as pessoas, de prestar-lhes algum auxílio ou benefício, uma assistência, favor, caridade, altruísmo, solidariedade; intenção de exercitar a cidadania, a fraternidade, o espírito de comunidade e a intenção de fazer os outros felizes pela supressão de seus sofrimentos (no caso, a realização de um transplante daria conta disso).

"Eu sou doador para manter essa nacionalidade que existe dentro da gente. Puxa! São irmãos, se eu morro um dia e os meus órgãos podem ser utilizados, por que não?" (P.30)

"Eu acho que a gente está neste mundo para ajudar as outras pessoas. Seria muito egoísmo deixar de ajudar alguém sabendo que isso não vai lhe causar nenhum mal, não custará nada!" (P.22)

\section{Continuidade da Vida do Receptor}

Esta categoria aglutina todos aqueles temas que remetem ao desejo do indivíduo em protelar a vida do outro através da doação do órgão e realização do transplante; vontade de fazer a vida continuar, de aproveitar todas as chances disponíveis para mantê-la ou postergá-la; vontade de salvar o receptor mediante a doação, de dar mais uma chance de a pessoa viver, ou então de sobreviver, para ficar mais um pouco junto à família e às pessoas que ama.

"É isso que eu tenho na cabeça: eu deixei a vida continuar aí...Eu decidi dar um tempo a mais para a pessoa para haver a oportunidade da vida melhorar, de ela ter a oportunidade de fazer alguma coisa e a vida continuar" (P.24)

"O motivo pelo qual eu sou uma doadora convicta é para poder ajudar uma pessoa a continuar sua vida. Para ela não ter sua vida acabada porque não encontrou alguém que se colocasse à disposição dela. O fator principal é dar continuidade à vida de quem está realmente precisando" (P.12)

\section{Reaproveitamento dos Órgãos}

Esta categoria está intimamente ligada com a primeira, pois não obstante o corpo seja uma matéria orgânica como outra qualquer, essa matéria, após a morte do indivíduo, pode ser utilizada por alguém que ainda precisa dela para sobreviver, sendo a doação uma oportunidade de "reciclá-la", de reaproveitá-la, dando-lhe ainda algum tipo de funcionalidade, um fim mais "nobre". O corpo é aqui apreendido como um conjunto de órgãos que devem ser aproveitados completamente, sem "desperdício".

"A doação de órgãos é pragmática no sentido de pessoas estarem precisando, pessoas não estarem precisando, pelo fato destas já estarem mortas. Haveria a funcionalidade de retirar de um corpo que não está mais precisando do órgão para pôr num que ainda precisa...seria até incômodo deixar algo em meu corpo não tendo mais utilidade nenhuma" (P.3)

"É uma coisa lógica assim: se não vai te fazer falta, por que você vai deixar estragar quando a outra pessoa está precisando disso para sobreviver e para levar a vida dela? ... é mais pela razão da utilidade, da necessidade, da praticidade" (P.31)

\section{Qualidade de Vida ao Receptor}

Diz respeito ao desejo de fazer com que a vida da pessoa que necessita de um órgão melhore a partir da realização do transplante. Expressa-se aqui o desejo de acabar com o sofrimento alheio, com a agonia das filas de espera, com o desespero das famílias que têm um membro doente; desejo de dar saúde às pessoas debilitadas pelas conseqüências provocadas pelo desfalecimento do órgão. Em acréscimo, foram também considerados os temas que se referem à intenção de "normalizar" a vida do eventual receptor, permitindolhe desfrutar de todas as oportunidades da vida social e familiar - das quais ele pode se ver obrigado a abster-se devido a seu desfalecimento orgânico.

"Eu acho que a doação é válida: muda a estrutura de uma pessoa que está necessitando, que está passando a vida inteira com problemas. (...) O transplante muda todo o ambiente dela; ela muda sua visão de família e vive intensamente a partir desse instante...” (P.21)

"A primeira coisa que me vem à mente quando eu penso em doação de órgãos são as outras pessoas. Para mim, é a felicidade de um cego, de uma pessoa que está morrendo por não ter um coração. (...) Eu sou doadora pois não quero ver a outra pessoa sofrer, uma pessoa cega - para mim isso é uma das piores coisas... eu acho que o mundo não tem sentido para uma pessoa cega, para mim não" (P.17)

\section{Necessidade Social da Doação}

Abrange temas que se referiram à doação de órgãos enquanto uma necessidade social, vendo-a como uma demanda social que deve ser satisfeita pois, ao envolver grande número de pessoas, diz respeito a um problema de saúde pública.

"Dôo para ajudar, porque eu sei que a fila é muito grande e o país não tem estrutura para bancar o transplante" (P.9) 
"Quem consegue hoje em dia receber um órgão é porque está na fila há muito tempo ou é porque tem dinheiro para conseguir. Senão, se for alguém que precisa mesmo, vai morrer esperando, porque a saúde está um caos e eles preferem dar prioridade para quem tem dinheiro. Se a população toda se conscientizar de que é preciso doar órgãos, a saúde vai melhorar um pouco, vai para frente um pouquinho" (P.12)

Razões Religiosas

Esta categoria representa: (1) temas que se referem a determinantes religiosos favoráveis ao ato de doar órgãos, tais como: atitudes ligadas a uma formação por valores religiosos, formas de relacionamento com o outro a partir do prisma religioso (ajudar ao próximo, amar os outros como se fossem irmãos) e desejo de crescimento pessoal através da ajuda ao próximo; (2) determinantes contrários à doação de órgãos, como filosofias místicas e crenças religiosas específicas (espiritualistas e/ou esotéricas).

"Religiosamente falando, o motivo de fazer a felicidade das pessoas é nossa busca aqui na terra: eu ajudo... porque preciso crescer. Crescer espiritualmente...” (P.23)

“(...) eu não dôo porque eu não estou pensando nesta vida, no bem que eu vou proporcionar neste momento, mas no bem que eu estaria proporcionando ao espírito dela, já que este [espírito] (...) está inserido num todo. Se eu doar um órgão eu poderia estar fazendo mal para essa pessoa por várias existências, então eu ficaria com um pouco de carma para carregar futuramente" (P.20)

\section{Razões Ligadas ao Transplante}

Esta categoria representa os temas que dizem respeito às orientações (bio)éticas que deveriam nortear a doação de órgãos. Expressa-se aqui a necessidade que as pessoas têm de saber qual será o destino do órgão eventualmente doado, assegurando-se de que ele não será comercializado, vendido, negociado ou roubado; preocupação acerca da forma como se realizará a doação e em quais circunstâncias. Refere-se também à insegurança das pessoas quanto à possibilidade de terem uma morte "induzida", "provocada" ou "adiantada" em razão de serem eventuais doadoras de órgãos, sinalizando para o receio de que os órgãos sejam retirados do corpo quando ainda há chances de a pessoa se recuperar.

"Não sei se é uma coisa comum: a gente tem sempre o receio de que por estar muito facilitado o mecanismo de acesso a esses órgãos, de repente você está 'meio morto' e você fique 'morto de fato' porque tem alguém interessado" (P.19)

"Aí é que está o problema: uma pessoa pode matar a outra só para retirar seus órgãos. Essa é uma predisposição da pessoa que quer comercializar esses órgãos. (...) Eu acho que isso é um problema sério, digamos, de 'humor negro': a pessoa pode ser morta para se retirar o órgão" (P.7)

\section{Corpo-Pessoa}

Ao contrário da primeira categoria, para a qual o corpo seria apreendido pelas pessoas tal como uma matéria orgânica como outra qualquer, esta categoria sinaliza para temas que ainda atribuem ao corpo morto, seja o próprio ou de um familiar, um investimento afetivo cercado por sentimentos, "energias", símbolos que de certa maneira fazem dele um representante autêntico e forte do familiar falecido ou mesmo do próprio indivíduo. Neste caso, o corpo não é meramente uma matéria indistinta, "genérica"; ao contrário, é um ícone do indivíduo, a prova de sua permanência, palco de atravessamentos espirituais e cósmicos.

"Se eu acredito na imortalidade da alma, então eu imagino que a partir do momento que eu morrer e a minha alma permanecer viva, então eu não gostaria de saber que aquele corpo que me pertenceu um dia foi mutilado em vão" (P.32)

"O corpo é uma memória afetiva da pessoa. Ele é um ícone da pessoa, por mais que esteja morta. Aquela constituição física de certa forma representa a pessoa, a memória da pessoa. (...) Eu acho que na medida que você viola o corpo da pessoa [para retirar o órgão a ser doado] você está violando a própria pessoa. (...) O corpo é o único bem da pessoa, e se ela não tiver autonomia nem sobre seu próprio corpo, então o que vai lhe restar?" (P.26)

\section{Sistema Brasileiro de Saúde}

Representa os temas que retratam a insegurança das pessoas no sistema brasileiro de saúde, refletindo na descrença com relação à capacidade dos médicos em efetivar adequadamente o diagnóstico de morte encefálica e à falta de condições dos hospitais públicos para dar suporte a um esquema de transplantes.

"Sou um indeciso em doar órgãos devido à falência dos órgãos de saúde pública. Não saberia, caso sofresse um acidente, se os médicos seriam capazes de identificar uma falência neurológica, por exemplo. (...) O atual sistema de saúde não está habilitado para identificar uma morte encefálica" (P.2)

"Eu seria um doador se o governo tivesse um plano eficientíssimo de distribuição de órgãos, de quem vai estar retirando esses órgãos, qual a estrutura para isso. Então seria uma infra-estrutura adequada para esse tipo de procedimento" (P. 22)

\section{Legislação sobre a Doação de Órgãos}

Diz respeito ao papel desempenhado pela "nova" lei de doação de órgãos sobre a opção das pessoas por serem indecisas. Expressa-se aqui a discordância dos 
participantes com respeito ao fato de todo brasileiro terse tornado um doador "presumido" ${ }^{3}$ de órgãos.

"Eu não concordo com essa forma atual de ser doador [refere-se à doação compulsória]. Eu não quero ir lá e falar que eu não quero ser um doador. Estaria, com isso, contrariando o que penso, mas, em contrapartida, vem a questão da lei, da obrigatoriedade. (...) Impor a uma pessoa que ela deve ser doadora... não é ela que está querendo, foi uma lei que determinou" (P.28)

"Se a legislação fosse uma coisa coerente, sabendo que esse órgão doado realmente iria para o corpo da pessoa que precisa dele, tudo bem, perfeitamente possível todos os brasileiros serem doadores compulsórios de órgãos" (P.7)

\section{Estudo 2}

O objetivo deste estudo foi verificar as diferenças nas freqüências de respostas dadas a cada uma das categorias identificadas no estudo anterior. A pressuposição fundamental deste estudo é a de que tais respostas refletem a maior ou menor importância (verificada por meio de uma escala ordinal) de cada uma das razões (expressas por cada uma das categorias do Estudo 1) dadas pelos participantes para serem doadores ou não doadores de órgãos.

\section{Participantes}

\section{Método}

Foram selecionados para participar deste estudo 90 estudantes (38 homens e 52 mulheres) de uma universidade pública do Estado de São Paulo (seleção aleatória). A média de idade foi de 22 anos e nenhum dos que participaram deste estudo fez parte do anterior.

\section{Elaboração e Aplicação dos Instrumentos}

Os dados foram coletados mediante a aplicação de dois questionários fechados (um para doador e outro para não doador), cujas questões foram formuladas a partir do conteúdo das categorias do estudo anterior. Assim, cada uma das categorias do grupo de doadores expostas na Tabela 2 se transformou numa questão fechada no presente estudo (questionário para doadores). Entretanto, como no Estudo 1 foi encontrada apenas uma categoria de razões para justificar a não doação, e

\footnotetext{
3 Trata-se da lei n. ${ }^{0}$ 9.434, de 4 de fevereiro de 1997, regulamentada pelo decreto n. 2.268 de 30 de junho de 1997. Uma das medidas dessa lei consistiu em tornar todo brasileiro um doador "presumido" de órgãos. Em 1998, essa doação "presumida" (ou "compulsória”) viria a ser revogada. Esse primeiro estudo foi realizado entre os anos de 1997-1998, daí a referência à doação presumida.
}

como no presente estudo não foram encontrados indecisos, optou-se por transformar as categorias de razões destes últimos (Tabela 2) em questões para justificar a não doação no atual estudo (questionário para não doadores) ${ }^{4}$, acrescentado, porém, mais uma, relativa ao nível de informação que os participantes possuíam sobre a doação (já que esse aspecto é comumente associado à não doação - principalmente pela mídia). Junto a cada questão havia uma escala (ordinal) de 11 pontos. $\mathrm{O}$ pesquisador perguntava se o participante era um doador ou um não doador de órgãos. Conforme a resposta, era-lhe dado o questionário correspondente: doador (sete questões) ou não doador (seis questões). Era dito ao participante que a sua colaboração consistiria em responder a um questionário formado por afirmações que representavam, cada uma, razões destinadas a justificar a opção dele por ser um doador ou não doador de órgãos. Ele era então instruído a assinalar um número que melhor dimensionasse a importância de cada razão expressa nas questões. A pontuação compreendia a escala entre " 0 " (zero), significando "nenhuma ou pouca importância", e "10" (dez), significando "máxima ou muita importância”.

\section{Procedimentos de Análise dos Dados}

Para a verificação das freqüências dos dados coletados foram elaborados dois Stat graphs 2D box plots-outliers, um para a freqüência de respostas do grupo de doadores e outro para o grupo de não doadores. Utilizou-se, para tanto, o pacote estatístico Statistica for Windows 5.0.

\section{Resultados}

Neste Estudo, dos 90 entrevistados 73 se consideraram doadores ( 30 homens e 43 mulheres) e 17 se consideraram não doadores (oito homens e nove mulheres). Conforme apresentado na legenda da Figura 1 , cada uma das questões formuladas e aplicadas neste estudo corresponde às categorias do estudo anterior. Analisando a distribuição de freqüências destas questões, pode-se notar que a maioria dos participantes elegeu como razão principal de sua opção por serem doadores a categoria "Continuidade da vida do receptor", acompanhada da categoria "Reaproveitamento dos órgãos". Esta última, apesar de ter a mesma mediana da

\footnotetext{
${ }^{4}$ Tal recurso tornou-se plausível haja vista que as questões do grupo de indecisos colocam problemáticas mais concernentes à não doação do que à doação: comércio de órgãos, morte premeditada, precariedade do sistema de saúde, desrespeito ao corpo, etc. (cf. Tabela 2).
} 


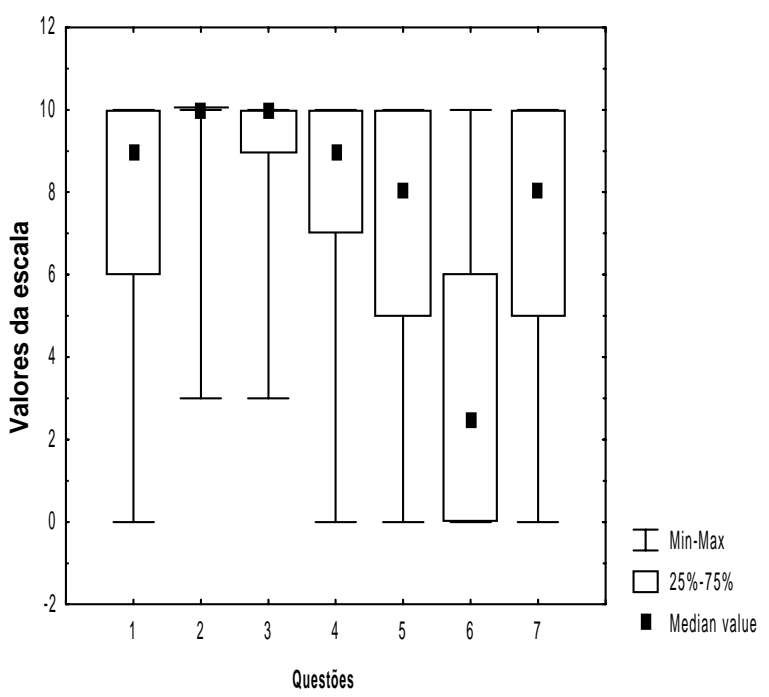

\footnotetext{
Questão 1: Corpo-matéria

Questão 2: Continuidade da vida do receptor

Questão 3: Reaproveitamento dos órgãos

Questão 4: Qualidade de vida ao receptor

Questão 5: Necessidade social da doação

Questão 6: Razões religiosas

Questão 7: Ajudar as pessoas
}

Figura 1. Distribuição da freqüência de respostas do grupo de doadores de órgãos, de acordo com as questões aplicadas a este grupo

anterior (ou seja, valor "dez", significando máxima importância - de acordo com a escala utilizada), apresentou uma variabilidade maior dos dados, isto é, apresentou uma quantidade maior de valores inferiores a "dez", quando comparada à quase unanimidade de respostas máximas da categoria "Continuidade da vida do receptor". Em seguida, com distribuições quase idênticas entre si, as categorias "Corpo-matéria" e "Qualidade de vida ao receptor". Ambas estas categorias apresentam medianas menores (valor "nove"), indicando sua menor importância para justificar, para os presentes participantes, sua opção por serem doadores comparando-se com as duas razões previamente apresentadas. Logo em seguida, também com medianas idênticas, seguem as categorias "Necessidade social da doação" e "Ajudar as pessoas". Estas duas apresentam uma mediana de valor "oito" e possuem uma variabilidade maior nos dados quando comparadas às quatro categorias anteriores (revelando, assim, menor convergência de respostas). Por fim, com a menor mediana de todas (valor "dois") segue-se a categoria "Razões religiosas", significando que, para os participantes deste estudo, a religião é pouco importante para justificar a opção deles por serem doadores de órgãos (visto que, pela escala utilizada, o valor "dois" significa pouco ou nada importante).

A Figura 2 apresenta, a distribuição de freqüências para o grupo de não doadores de órgãos deste estudo.

O mesmo raciocínio aplicado à análise dos dados do grupo de doadores foi aplicado aqui. Nesse sentido, cada

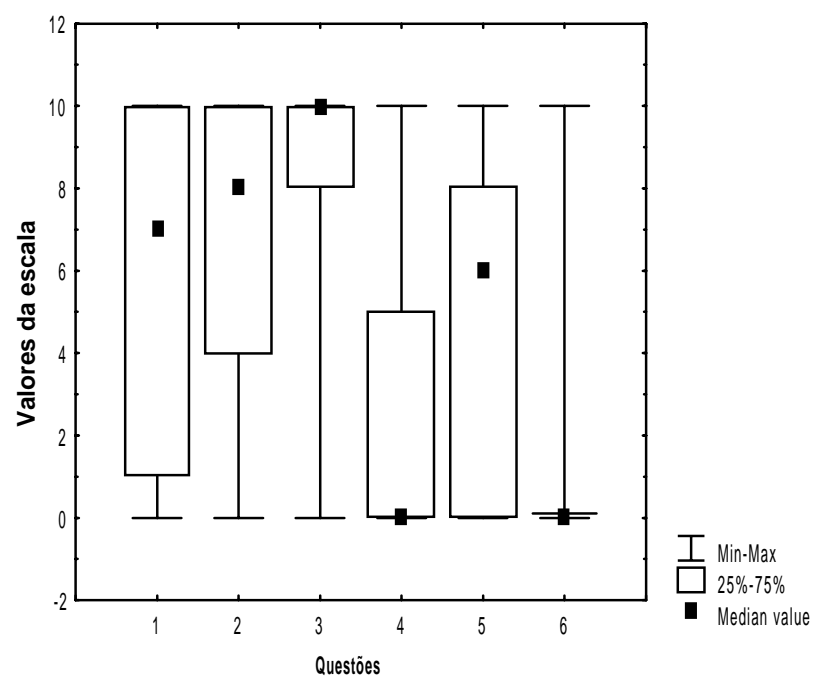

Questão 1: Razões ligadas ao transplante

Questão 2: $\quad$ Sistema brasileiro de saúde

Questão 3: Legislação sobre doação de órgãos

Questão 4: Sistema brasileiro de saúde

Questão 5: Corpo-pessoa

Questão 6: Razões religiosas

Figura 2. Distribuição da freqüência de respostas do grupo de não doadores de órgãos, de acordo com as questões aplicadas a este grupo

uma das questões acima apresentadas corresponde às respectivas categorias para o grupo de não doadores do estudo anterior, com a exceção da categoria "Informações sobre a doação de órgãos", conforme já justificado. Pela observação da Figura 2, nota-se que a razão citada como a mais importante para justificar a opção pela não doação foi "Legislação sobre a doação de órgãos" (cuja mediana é "10"). Em segundo lugar na distribuição vem "Sistema brasileiro de saúde" (mediana de valor "oito"). Em seguida está a categoria "Razões ligadas ao transplante", cuja variabilidade dos dados é bastante grande, comparada às outras categorias. "Corpo-pessoa" apresentou uma mediana próxima à da categoria anterior ("Razões ligadas ao transplante"), embora, neste caso, o 
número de respostas com valores baixos tenha sido maior (notar que o box inclui, no caso de "Corpo-pessoa", até o valor "zero", ou seja, nenhuma/pouca importância). Finalmente, a razão menos importante para justificar a não doação (já que apresentou quase unanimidade na atribuição do valor "zero") foi "Razões religiosas" (mediana valor "zero"). Este último resultado sugere a baixa importância da religião enquanto uma razão explícita para justificar a não doação de órgãos.

\section{Estudo 3}

O objetivo deste estudo foi dar destaque a duas importantes variáveis que surgiram, tanto no decorrer dos dois estudos anteriores (principalmente no primeiro), quanto na revisão da literatura científica especializada: as relações existentes entre medo da morte, religião e doação de órgãos. Na literatura, tanto o medo da morte (Kopfman \& Smith, 1996; Shepherd \& Lefcourt, 1992; 1995), quanto os aspectos religiosos (Kent \& Owens, 1995; Radecki \& Jaccard, 1997; Riether \& Mahler, 1995), estão associados à não doação de órgãos. O Estudo 1, embora tenha sido conduzido numa perspectiva qualitativa, também sugeriu a possibilidade de conexões entre o medo da morte e a opção pela doação de órgãos (doador ou não doador).

\section{Participantes}

\section{Método}

No total, fizeram parte deste estudo 62 estudantes de uma universidade pública do Estado de São Paulo (seleção aleatória). Destes, 15 eram homens e 47 eram mulheres. As idades variaram entre 17 e 26 anos. Aqueles que participaram deste estudo não fizeram parte dos anteriores.

\section{Elaboração e Aplicação dos Instrumentos}

Os dados foram coletados mediante dois instrumentos, cada um ligado às duas variáveis da pesquisa: para o caso do medo da morte, foi utilizada a Escala Multidimensional para Medir o Medo da Morte (EMMM), elaborada originalmente por Hoelter (1979), posteriormente traduzida e adaptada ao contexto brasileiro por Kovács (1985). Para construir a escala, o autor (Hoelter, 1979) definiu o medo da morte como uma reação emocional evolvendo sentimentos subjetivos de desagrado e preocupação, baseados na contemplação ou antecipação de qualquer das várias facetas relacionadas à morte, supondo serem esses sentimentos conscientes (Kovács, 1985). A escala é composta por oito dimensões, cada uma avaliando um aspecto distinto do referido medo. Ao todo, são 42 itens, os quais são pontuados mediante cinco marcas, variando entre "discordo plenamente" (marca "um") e "concordo plenamente" (marca "cinco").

Por outro lado, no que concerne à variável religião, foi elaborado um pequeno questionário de três questões, as quais tentavam identificar: a) se o participante tinha, ou não, uma religião. Caso ele declarasse ter uma: b) qual era essa religião e, enfim, c) o "grau" de envolvimento com essa religião. Neste último caso, foi utilizada uma escala nominal de dupla escolha: "religioso praticante" e "religioso não praticante". O participante que declarou não ter uma religião foi considerado "não religioso" (pouco ou nenhum grau de envolvimento religioso, se comparado aos religiosos praticantes e não praticantes). A EMMM e o questionário sobre religião foram aplicados juntos, tanto para aqueles que se identificavam como doadores, quanto para os não doadores.

\section{Procedimentos de Análise dos Dados}

A análise dos dados se fez de modo quantitativo através da aplicação de dois testes estatísticos não paramétricos, a saber: o teste do qui-quadrado e o de Mann-Whitney (prova $U$ ). O primeiro foi destinado à verificação de semelhanças, estatisticamente significativas, entre o grau de envolvimento religioso dos participantes (religioso praticante, não praticante, não religioso) e a opção deles pela doação de órgãos (doador, não doador). $\mathrm{O}$ teste $U$ de Mann-Whitney foi destinado à verificação de relações significativas entre o medo da morte e a opção pela doação de órgãos (doador ou não doador). O nível de significância adotado para ambos os testes foi de $5 \%$.

\section{Resultados}

Dos 62 entrevistados, 52 se consideraram doadores. Destes, 23 eram religiosos praticantes, 18 não praticantes e 11 não religiosos. Foram encontrados dez não doadores, dos quais dois eram religiosos praticantes, quatro não praticantes e quatro declararam não ter uma religião. No que diz respeito ao credo particular, houve uma predominância, no total, de católicos (36 pessoas), seguido dos espíritas (quatro) e dos evangélicos (quatro) e daqueles que não definiriam nenhuma religião em específico (três). Ao todo, são 47 pessoas que declararam ter alguma religião (praticantes e não praticantes) e 15 que se consideraram não religiosos. $\mathrm{Na}$ categoria "religioso", temos: 25 praticantes e 22 não praticantes. Há uma predominância, no caso dos católicos, de não praticantes (16 praticantes contra 20 não praticantes). Entre os não doadores encontramos apenas católicos (seis no total), dos quais dois são praticantes e quatro não praticantes; o restante declarou não ter uma religião (quatro pessoas). 
A prova do qui-quadrado foi utilizada para verificar a existência de relações significativas entre o grau de envolvimento religioso (praticante, não praticante, não religioso) e a doação de órgãos (doador, não doador). Entretanto, como o número de não doadores encontrado neste Estudo é muito pequeno $(n=10)$, tivemos de lançar mão de um recurso metodológico para tentar garantir o poder desta prova estatística. A variável "grau de envolvimento religioso" foi dividida, como apresentado antes, em três subcategorias: "religioso praticante", "religioso não praticante" e "não religioso". Para impedir que os valores destas subcategorias fossem muito pequenos para o cálculo do qui-quadrado, juntamos, num único caso, as subcategorias "religioso não praticante" e "não religioso". Ao uni-las, partimos do princípio de que "religioso não praticante" + "não religioso" caracterizam um grau menor de envolvimento religioso do que os praticantes. Em outras palavras: é como se considerássemos uma polaridade entre religioso e não religioso, o primeiro como sendo o máximo de envolvimento e o segundo como sendo um grau menor, mínimo ou mesmo nulo desse mesmo envolvimento. $\mathrm{O}$ resultado da prova (já com a correção de Yats - segundo Levin, 1987) sugere que não há diferença, estatisticamente significativa, entre o envolvimento religioso e a opção pela doação de órgãos ( $\left.\underline{c}_{\text {obs. }}^{2}=1,11 ; g l=1 ; c_{0.05}^{2}=3,84\right)$. Em outros termos: neste Estudo, pessoas com alto grau de envolvimento religioso (praticantes) não diferiram, no que concerne à opção por doar ou não doar órgãos, de pessoas com menor envolvimento, ou mesmo de pessoas que declararam não ter uma religião (religioso não praticante + não religioso).

No caso dos resultados da prova $U$, para a Escala Multidimensional para Medir o Medo da Morte, as únicas relações estatisticamente significativas $(p<0,05)$ que se observaram são apresentadas pelas Figuras 3 e 4.

As Figuras 3 e 4 apresentam as únicas dimensões da $E M M M$ para as quais se constatou relações estatísticas significativas, aferidas pela prova $U$, com a opção por se doar ou não doar órgãos. São as dimensões "Medo de morrer" (Figura 3) e dimensão "Medo de ser destruído" (Figura 4). Como pode ser observado nestas figuras, os não doadores tenderam a apresentar os escores significativamente mais altos $(p<0,05)$ nestas respectivas dimensões, se comparados aos doadores. Quanto mais altos são os escores, maior é o medo diante de cada faceta (ou dimensão) avaliada.

Segundo Kovács $(1985,1992)$, a dimensão "Medo de morrer" lida mais com o processo específico de morrer do que com quaisquer conseqüências que acompanhem esse processo. Já "Medo de ser destruído"

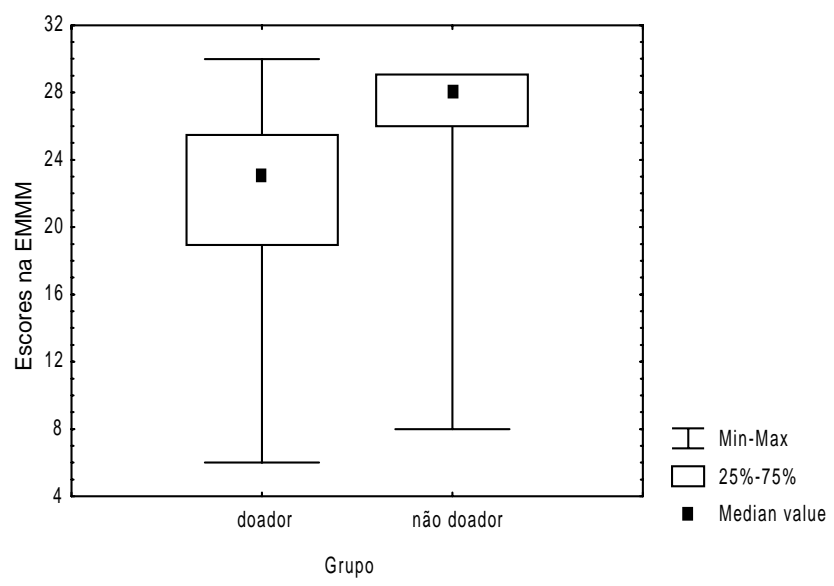

Figura 3. Distribuição das freqüências referentes à dimensão "medo de morrer", da escala multidimensional para medir o medo da morte

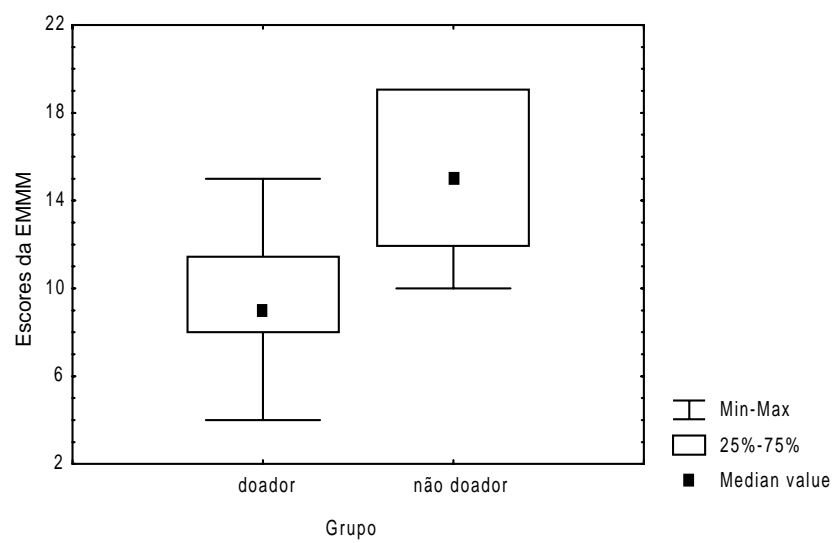

Figura 4. Distribuição das freqüências referentes à dimensão "medo de ser destruído", da escala multidimensional para medir o medo da morte

lida com a destruição do corpo imediatamente após a morte. A Tabela 3 apresenta os itens que compõem as duas dimensões mencionadas.

\section{Discussão}

Embora os três estudos, acima apresentados, tenham tido desenhos metodológicos distintos, torna-se possível uma discussão em conjunto, em vista do caráter complementar de cada um deles em relação ao outro. Entretanto, como o Estudo 1 foi mais extenso, tanto em termos de dados coletados, quanto de hipóteses levantadas, vamos elegê-lo como roteiro de discussão. Nesse sentido, cinco principais aspectos serão abordados, em vista dos objetivos específicos da pesquisa e do referencial teórico adotado: a percepção do próprio 
Tabela 3. Itens que Compõem as Dimensões "Medo de Morrer" e "Medo de Ser Destruído" (Escala Multidimensional para Medir o Medo da Morte - EMMM)

\begin{tabular}{ll}
\hline Dimensão & Itens \\
\hline Medo de morrer & $\cdot$ Tenho medo de morrer lentamente \\
$\cdot$ Tenho medo de morrer num incêndio \\
$\cdot$ Tenho medo de sofrer muita dor ao morrer \\
$\cdot$ Tenho medo de morrer de câncer \\
$\cdot$ Tenho medo de morrer asfixiado (incluindo afogamento) \\
$\cdot$ Tenho medo de morrer violentamente
\end{tabular}

Medo de ser destruído

- Após a minha morte, meu corpo poderia ser usado para estudos científicos

- Não quero que estudantes de medicina usem meu corpo para treinamento

- Não gosto de pensar que serei cremado

- Não quero doar meus olhos para que sejam usados após a minha morte

corpo; a visão do "outro" no contexto da doação; a relação desta última com a percepção da morte; religião e doação de órgãos e, enfim, aspectos ligados à cultura e à origem da população estudada (estudantes universitários). Será em função destes aspectos que os resultados dos três estudos anteriores serão articulados.

Antes, porém, é preciso acrescentar um breve comentário sobre a natureza dos dados obtidos nesta pesquisa. Como o número de participantes do Estudo 1 é pequeno, não é possível predizer com exatidão qual sua distribuição na população de estudantes considerada. O máximo que se pode afirmar, em vista do tipo de metodologia utilizada (qualitativa e descritiva), é que eles dão acesso a um determinado "campo de significação" (Souza Filho, 1995) relativo à doação de órgãos, isto é, indicam como o assunto é elaborado e discernido por determinadas categorias sociais (no caso, uma categoria de estudantes universitários). A própria análise de conteúdo empreendida no Estudo 1 orientou-se pela meta de levantar possíveis indicadores para uma compreensão mais acurada da doação de órgãos. Não obstante o aumento do número de participantes dos Estudos 2 e 3, a preocupação central permaneceu como sendo a de coletar dados que aprofundassem as hipóteses sinalizadas no estudo inicial (Estudo 1). A análise geral e a discussão a seguir devem ter em conta que uma generalização a partir dos dados aqui obtidos deve ser vista com reserva, haja vista a metodologia empregada e a natureza exploratória da pesquisa.

Além disso, outro elemento importante consiste no baixo número de não doadores encontrados na pesquisa como um todo. No Estudo 1 encontrou-se apenas um não doador, e nos demais a proporção sempre ficou bem abaixo à dos doadores (17 e 10, respectivamente). Não é possível predizer se esta é, efetivamente, a distribuição "normal” desta variável na população estudada, haja vista a própria metodologia empregada para se escolher os participantes. Nesse caso, é plausível estabelecer, no máximo, uma discussão que pondere o caráter particular da amostra de não doadores, principalmente porque na época desta pesquisa ainda vigorava a doação compulsória no país, o que já não ocorre hoje. A análise desse grupo (não doadores) pode indicar, em termos de hipóteses, possíveis pontos a serem aprofundados em outras populações e mediante outros estudos mais extensivos. Ademais, o fato de se adotar uma perspectiva exploratória para o Estudo 1 (o qual servirá como roteiro da discussão a seguir) facilita um entrosamento e uma imbricação maior entre os dados e o referencial teórico adotado, conduzindo-os (dados e referencial teórico) de maneira conjunta e única.

\section{O Corpo Natural e a Alma Imortal}

Ao desenvolvermos uma análise sobre a percepção apresentada pelos participantes a respeito de seus próprios corpos, suscitada pelos dados obtidos no Estudo 1, notamos, na mesma linha do que sugere Aulagnier (1979/ 1985, 1986/1990), uma forma de “divisão" entre indivíduo e corpo, entre identidade e corpo, ou entre corpo e alma. Quando a maioria dos doadores afirmou que o corpo é apenas "matéria" (Tabela 2), a visão que parece predominar é a do organismo, do corpo científico, médico, propriamente fisiológico, sem nenhuma carga de investimento capaz de fazê-lo, mesmo depois de morto, um representante do indivíduo junto à família. Quando alguns entrevistados falam de sua percepção do 
corpo enquanto uma "matéria orgânica como outra qualquer", eles provavelmente estão indicando a relação deles com o organismo que constitui a cada um, ou seja, estão revelando a relação existente entre "eu" e "corpo" (Aulagnier, 1979/1985), pois é o "eu" que detém o conhecimento da morte do corpo e de seu destino a partir daí.

Para grande número dos entrevistados que se consideraram doadores (Estudo 1), a alma é mais importante que o corpo, sendo este último considerado apenas um invólucro, uma casca que serve de apoio provisório e efêmero àquela. É curioso notar, a esse propósito, que não obstante apenas um reduzido número de pessoas tenha se referido ao fator religioso como razão explícita de sua opção (vide Tabela 2), mesmo assim um senso religioso perpassou suas respostas, tal como o que postula a existência de uma alma, de "algo" que vai além da mera estrutura física, carnal. Essa suposta divisão entre alma e corpo equaciona este último como um termo secundário após a morte, algo que não se usa mais para nada, nem para garantir àquela uma caminhada segura no além. Pelo contrário: é justamente essa divisão que talvez facilite a doação, pois ela dá uma segurança para o indivíduo de que ele não é finito, vulnerável e totalmente dependente de seu corpo para ser e desaparecer (Aulagnier, 1979/1985). A pergunta que se coloca é a seguinte: seria essa divisão um apanágio para o "medo da morte", para o medo ou pavor do sofrimento que o corpo potencialmente esconde? Decorrência disto surge uma hipótese: parece que no grupo de doadores do Estudo 1 a divisão entre alma/corpo pode ter contribuído com a doação de órgãos, porquanto então se tenha revelado um fator de facilitação a seu favor. Já no grupo de indecisos e não doadores daquele estudo, o corpo figura muito "próximo" à identidade da pessoa, sendo inclusive o representante dos desejos do indivíduo mesmo depois de morto. Por exemplo: há pessoas que ficariam indecisas devido ao receio de terem uma morte "premeditada" em razão de serem doadores. O que isso pode estar revelando? Talvez possamos conjecturar duas coisas: uma, o medo da morte - ou pelo menos de um "tipo" de morte (como veremos mais à frente); outra, a estreita relação existente entre o "corpo" e o "eu" (na perspectiva levantada por Aulagnier, 1986/1990). No momento vamos ficar com esta última, sondando algumas de suas implicações.

No grupo de indecisos do Estudo 1 houve uma preocupação dos entrevistados a respeito da responsabilidade que a doação de órgãos teria no caso de suas mortes. A visão predominante indica o receio de que, sendo doadores, eles possam ser prejudicados, "mortos" prematuramente (vide Tabela 2 e Estudo 2). Então, a ênfase está posta antes na relação com a morte do que com o corpo, estando este investido libidinalmente de tal forma que retrata a própria sobrevivência do "eu" (Aulagnier, 1986/1990; Green, 1982/1988). Ou seja: não basta dizer que o corpo "não vai servir para mais nada depois de morto" (vide a categoria "Corpo-matéria", no Estudo 1); o que importa é garantir todos os recursos para que a morte não seja provocada, trazida "antes da hora", para que o indivíduo possa continuar vivendo e desfrutando do tempo que ainda lhe resta. $\mathrm{O}$ indeciso parece ser um indivíduo que vê a morte como algo "natural", não acidental (através de um médico inescrupuloso, por exemplo). O corpo parece ser aqui visto como algo vulnerável, passível de ser prejudicado pelo outro; corpo e indivíduo são cúmplices de um mesmo desejo: manter a vida acima de todas as coisas.

De um modo geral, tanto os doadores do Estudo 1 quanto do Estudo 2 sinalizam para uma apreensão da matéria como descaracterizada do ponto de vista da individualidade que ela representava ao circunscrever, na identidade, um corpo individualizado. A morte torna a matéria indistinta do restante da natureza. Morto o indivíduo, o corpo é matéria útil, sem face, "universal". Para muitos, é o espírito que individualiza, que particulariza e leva consigo a essência que foi, ou é, o indivíduo. No Estudo 2 essa tendência manteve-se vigorosa, haja vista a importância que "reaproveitamento dos órgãos" teve no tocante à opção favorável à doação. Também nesse segundo estudo houve indícios da forma como o corpo é percebido pelos participantes, ao menos no contexto universitário: um corpo "reciclável", disposto às intervenções médicas, solidário da técnica dos transplantes. Ainda pode ser exigida uma funcionalidade para o corpo morto, uma utilidade: não pode ser "desperdiçado", "jogado fora". A doação cria e estimula uma "pós-utilidade" do corpo.

\section{A Visão do "Outro"}

Vamos partir da seguinte premissa: a doação de órgãos surgiu devido à falta de algo para alguém: um rim que não funciona direito, um fígado que está com debilidades devido a um câncer, o coração que já não bombeia a contento o sangue para o organismo, ou então córneas que já não trazem mais a luz para dentro do indivíduo. Em todos esses casos, há falta de alguma coisa. A pessoa que precisa de um órgão para sobreviver tem alguma disfunção, algum tipo de "precariedade", enfim, uma necessidade. Ora, como ela surgiu? Evidentemente, por alguma contingência ambiental ou hereditária; mas, não 
só por isso: também surgiu graças à contraposição, feita pela medicina, entre um corpo "ideal” e um corpo "debilitado", "defeituoso". O primeiro reenvia à metáfora da máquina da qual é possível extrair os melhores resultados, da qual se espera a harmonia do conjunto e a eficiência de cada uma de suas partes constitutivas (Le Breton, 1990). O corpo "defeituoso", ao contrário, revela uma desarmonia, um "ruído" estranho e indevido, uma improdutividade (Certeau, 1990/1996). A tarefa da medicina parece consistir, em parte, em eliminar o descompasso entre os dois modelos, em trazer de volta o corpo ideal àquele que sofre com a doença, com $O$ enfraquecimento e com a suposta "falta". A doação de órgãos não poderia herdar outra coisa senão essa ética onde o indivíduo torna-se um "receptor", um "transplantado", um "inválido equipado" (Virilio, 1993/ 1996), devolvendo ao indivíduo o gozo de ver-se novamente completo, saudável e "normal".

Sobretudo de 1997 para cá, com as discussões suscitadas pela nova lei de transplantes, a sociedade brasileira pôde presenciar inúmeras informações referentes à doação de órgãos. Não foram raros os casos onde pessoas eram mostradas em seus leitos nos hospitais, fazendo hemodiálise ou algum outro tipo de tratamento. Também tivemos a oportunidade de ver famílias desesperadas com um ente seu morrendo pela falta de um órgão; crianças que, ao invés de terem o futuro inteiro pela frente, eram flagradas nos corredores de hospitais lotados e com poucos recursos. Em todos esses exemplos, nós temos de reconhecer o lugar que é atribuído a cada um dos elementos envolvidos no processo de doação e transplantação de órgãos, ou seja, tanto o doador como o receptor. E no caso deste último, o lugar parece ser o da falta que deve ser corrigida; e o daquele, o da plenitude que deve ser partilhada. Para cada um desses termos, uma caracterização implícita do corpo. O raciocínio da doação de órgãos consiste em criar um gradiente em função do qual um órgão migre de um corpo para outro: desequilíbrio que sustenta a lógica do procedimento.

Os dados dos Estudos 1 e 2 apontam para uma percepção da doação de órgãos enquanto uma forma valiosa de auxílio social, um modo de colaborar com as pessoas. Segundo apuramos entre os entrevistados do Estudo 1, o indivíduo que necessita de um órgão não tem condições suficientes para levar uma vida "normal", não consegue trabalhar, sofre muito, não pode se relacionar com os demais de maneira eficiente, pois ou está prostrado numa cama, ou então muito próximo disso, enfim, foi caracterizado como sendo infeliz, levando uma vida "sem sentido", já que não pode usufruir dela em toda sua plenitude. Tudo isso aponta para um outro incompleto, necessitado. Portanto, podemos interpretar o desejo de "ajudar as pessoas", e de dar "qualidade de vida ao receptor" (vide Tabela 2), como decorrentes de duas vertentes principais: uma, da representação social da doação de órgãos (como algo capaz de eliminar o sofrimento alheio), tal como analisamos acima; outra, e conseqüente da anterior, a representação do "outro" como marcado por uma "falta" que o doador se acha na posição de suprir.

\section{Morte: A Última Quimera}

Por detrás da categoria "Continuidade da vida do receptor", citada como uma das principais razões para as pessoas doarem órgãos (vide Tabela 2 e Estudo 2), está alojada uma concepção que valoriza a vida e a sua preservação acima de tudo. A pergunta a se fazer aqui consiste na seguinte: por que as pessoas acreditam na necessidade de continuar a vida, de dilatá-la na esteira do tempo, lançando-a sempre um pouco mais além? Para respondermos a esta pergunta, vamos partir de algumas premissas centrais: (1) As respostas dadas pelos participantes a respeito da importância de se continuar a vida (Estudo 1) ancoram-se num imaginário cultural que investiu nesta última uma enorme relevância em detrimento da morte; (2) A doação de órgãos figura como um instrumento destinado à manutenção da vida, revestindo-se, assim, de uma finalidade socialmente valorizada, pois responde às necessidades de um dado momento da sociedade (Estudo 2). Decorrência dessas últimas colocações: (3) o desejo de doar órgãos pode surgir devido à adequação entre uma suposta necessidade cultural - a manutenção da vida ou protelação da morte - e a crença na eficiência com que a doação de órgãos responde a essa necessidade.

Já sinalizamos, na introdução deste artigo, para alguns fatores culturais passíveis de explicar a origem da valorização atual da vida nas sociedades ocidentais (Ariès, 1977/1990; Green, 1982/1988; Kovács, 1992; Le Breton, 1990). Os dados das entrevistas do Estudo 1 e dos questionários do Estudo 2 exibem uma aspiração intensa, por parte dos participantes, para fazer com que a vida seja mantida graças ao trabalho iniciado na doação de órgãos. Segundo boa parte dos entrevistados (Estudo 1), torna-se uma espécie de "egoísmo" e "falta de humanidade" deixar de ajudar as pessoas a continuarem suas vidas, deixá-las morrer sabendo que o corpo não mais faria falta ao doador (após a sua morte). Nesse contexto, os entrevistados se mostraram revoltados e, inclusive, indignados com uma sociedade onde as pessoas não se preocupam com a qualidade da vida das outras, 
onde não abdicam de seus próprios interesses para atender a uma demanda social, para utilizar uma tecnologia tão arduamente conquistada (a dos transplantes). Enfim, eles não entendem como alguém pode deixar de doar seus órgãos.

A doação de órgãos faz parte do "mundo humano", afinal, nosso corpo nunca faria um transplante sob condições naturais. É preciso uma mediação humana para ser efetuada a transferência de um órgão de um corpo a outro; mediação, portanto, não "natural", mas forjada. Dessa forma, parte do que sustenta os transplante talvez seja uma espécie de vitória da cultura sobre a natureza, pois caso a manutenção da vida dependa dela, seguramente ela não irá falhar. E se falhar, a reação não é de resignação ou convencimento, mas de revolta, de indignação, pois a responsabilidade pelo fracasso ou sucesso do procedimento dependia em grande parte das ações humanas. Dependia da habilidade em se manejar as técnicas, os instrumentos, e dependida, igualmente, da doação humanamente responsável de um órgão para fazer funcionar os procedimentos médicos, para funcionar a reescritura do curso dos acontecimentos sobre um solo que nos seja conhecido e disposto a nossas manipulações (Certeau, 1990/1996). A “indignação" dos entrevistados do Estudo 1 sobre a opção desfavorável à doação talvez seja agora compreensível, e não podemos deixar de mencionar que ela pode estar calcada sobre um imaginário cultural que coloca sobre a morte uma pedra que a impede de ser encarada de frente (Ariès, 1977/1990; Kovács, 1992). A consciência de cada um parece estar designada pela responsabilidade de afastar o tabu da morte, de fazê-lo uma quimera distante, uma miragem ou um fantasma que só aparece se não convenientemente vigiado: doar órgãos poderia ser a garantia, do ponto de vista particular, de que ela está longe, de que ela é secundária. O indivíduo reproduz uma ordem simbólica que faz da vida um bem que deve ser defendido tão intensamente proporcional ao abafamento da morte, à sua expulsão do cenário contemporâneo, infiltrando-a em campos cada vez mais mediados pelas "tecnologias da vida".

Por outro lado, no Estudo 3 pudemos verificar duas relações significativas entre o medo da morte e a opção pela doação de órgãos. Conforme apresentado anteriormente, as dimensões "Medo de morrer" e "Medo de ser destruído" tiveram os maiores escores entre os não doadores, comparativamente aos doadores. Como já houvera sido conjecturado no Estudo 1, entre os indecisos, e/ou não doadores, haveria uma relação mais estreita entre o eu e o próprio corpo. De fato, a categoria "Medo de ser destruído" aborda aspectos que retratam o modo como o corpo seria tratado após a morte (Tabela 3). Os não doadores parecem nutrir o medo de que seus corpos sejam destruídos ou então tratados de modo não conveniente após sua morte. A doação poderia estar figurando, então, como um fator negativo, potencializando o medo, ou o receio, da mutilação do corpo morto, da sua destruição ou violação. Portanto, o medo de morrer, essa faceta específica do medo da morte, esteve, no Estudo 3, associado à própria percepção do corpo e à representação social da doação (como potencialmente capaz de "adiantar" a morte, torná-la prematura - em razão, por exemplo, de uma comercialização de órgãos, tal como apontado no Estudo 1 e reforçado no Estudo 2). O que parece estar em jogo aqui é o medo da fragmentação da imagem corporal (Schilder, 1950/1981).

\section{A Bíblia e o Laboratório}

Os dados dos três estudos foram praticamente unânimes em apontar a fraca relação existente entre doação de órgãos e religião, pelo menos entre os estudantes universitários pesquisados. Os fatores mais relevantes para justificar a doação estiveram ligados a dois grandes grupos de razões: o primeiro, à necessidade de ajudar o outro, postergando-lhe a vida e devolvendo-lhe a saúde. O segundo grupo se refere à percepção do corpo como algo disposto às intervenções médicas, um corpo aberto e funcional. Mesmo entre os não doadores, grupo ao qual são associados obstáculos devido a crenças religiosas (como apresentado na introdução), não foram encontradas nenhuma evidência nesse sentido. A religião, independente de qual seja e do grau de envolvimento do participante, foi sempre citada como a menos importante para justificar as opções dos entrevistados (seja para a doação ou não doação - vide, especialmente, os Estudos 2 e 3$)$.

A hipótese que pode interpretar esses dados deve, segundo nosso ponto de vista, estar ligada às características do ambiente universitário. Da mesma forma, tais características podem ser associadas a um outro resultado discrepante: o número de doadores, desde o primeiro até o terceiro estudos, foi majoritário. Os não doadores foram sempre encontrados em reduzidas proporções (um, 17 e dez, respectivamente). Curiosamente, segundo a Associação Brasileira de Transplantes de Órgãos (ABTO), a atual taxa de não doadores no Estado de São Paulo, medida pelo índice de expedição de documentos de identidade, é de $62 \%$ (Jornal de Piracicaba, 2000, caderno B, p.4). Não é possível, aqui, fazer um estudo comparativo com os dados da ABTO, pois seria necessário um discernimento 
quanto às razões que configuram esse índice e quanto às particularidades da população abrangida. Entretanto, na universidade, de acordo com os dados encontrados em nossas pesquisas, a doação parece ser mesmo uma questão de indiscutível relevância social. Tanto é assim que a não doação sempre esteve ligada à incerteza dos participantes quanto aos procedimentos bioéticos ("Razões ligadas ao transplante") que deveriam nortear todo o processo de transplante (Estudo 2, principalmente), e nunca ao valor do ato de doar, ele mesmo apreciado e aprovado.

Não é possível afirmar, unilateralmente, que os não doadores desta pesquisa sejam pessoas "narcisistas" ou simplesmente "egoístas". Segundo nossos estudos, é mais provável que o não doador pondere tal opção a partir da própria representação social da doação de órgãos, no sentido em que ela é retratada, negativamente, como "provocando" a morte devido a interesses de comercialização de órgãos, ou então sendo associada à mutilação, ou destruição, do corpo após a morte (vide Tabela 3, Figuras 2 e 3). Por outro lado, a opção por ser um doador se encontra ligada a certas diretivas que colocam especial importância na ajuda, no auxílio social e na solidariedade. Um forte apoio para esse desejo altruísta, entretanto, pode ser deduzido a partir da visão de corpo predominante no meio universitário: um corpo cuja textura é, a princípio pelo menos, desinvestida de aspectos religiosos ou "supersticiosos".

Mantemos, nesse sentido, a hipótese de que, na universidade, dada suas características singulares, o referencial religioso cede espaço em detrimento de concepções mais "objetivas”, ligadas aos fatos, tais como ajudar as pessoas, continuar a vida delas e aproveitar, racionalmente, o alcance e a finalidade prática de uma tecnologia moral e cientificamente legitimada: os transplantes de órgãos. Apesar de não ter havido relação significativa entre grau de envolvimento religioso e doação de órgãos (Estudo 3), pudemos constatar, ao contrário do que em geral se acredita como verdade, que entre os não doadores predominaram os católicos. Os evangélicos (adventistas e batistas, na amostra do Estudo 3) optaram por doar órgãos. Por outro lado, predominaram, também entre os doadores, os católicos, inclusive com um alto índice da categoria "religioso não praticante", o que já é "típico" a propósito dessa religião (muitas vezes usada como símbolo de status social).

Como uma conclusão geral, é possível imaginar que a doação de órgãos oscila entre a relação com o outro, caracterizado como aquele que cria a demanda e exige um posicionamento do doador; a relação com o próprio corpo que, no caso dos doadores, parece significar uma apreensão "racional", pautada por finalidades práticas e imediatas; a percepção da morte que, no caso dos doadores, parece ser alimentada por um desejo de ver a vida maximizada em toda sua plenitude, em consonância com o retrato cultural da morte no ocidente (transformada em fator quase residual, acidental e mediada pelas tecnologias da vida). É também possível pensar que, no âmbito acadêmico, respeitadas as devidas restrições metodológicas, a religião não parece ser um fator, seja de resistência, seja de facilitação à doação de órgãos, predominando o desejo de ajuda e solidariedade. Em compensação, entre os não doadores pode ser destacada a representação social da doação de órgãos (no sentido de que envolve "imagens negativas", muitas vezes divulgadas pela mídia, de comércio de órgãos, de morte "premeditada", de procedimentos que não obedeceriam à ética - ou bioética) como um fator de resistência, em específico no caso acadêmico. A lei dos transplantes, de acordo com o Estudo 2, foi caracterizada como a principal razão para a não doação de órgãos, uma vez que ela foi implantada, segundo os participantes, sem obedecer a um amplo debate público. Os não doadores não concordaram com o fato de todo brasileiro ser um doador "compulsório" de seus órgãos. ${ }^{5}$

Os resultados desta pesquisa parecem apontar para o fato de que doar órgãos não é apenas e tão somente uma questão de ter mais ou menos informações sobre os procedimentos técnicos envolvidos (embora isso, sob certos aspectos, não deva ser ignorado). Em linhas bastante gerais, os dados apontam para a importância da percepção do próprio corpo como requisito favorável ou desfavorável à doação, seguida do desejo de ajudar as pessoas que sofrem em razão da debilidade de um órgão. Além de ajudar, a intenção é manter a vida, distendê-la tanto quanto isso seja possível. Outra conclusão importante é a desmistificação, pelo menos parcial, da religião como fator de obstáculo à doação. No estrito contexto universitário, a religião não parece ser uma variável forte o bastante para explicar a recusa ou aceitação por ser um doador. Naturalmente, a questão de estudar outras populações ainda permanece em aberto.

\section{Referências}

Ariès, P. (1990). A bistória da morte no Ocidente (L. Ribeiro, Trad.). Rio de Janeiro: Francisco Alves. (Original publicado em 1977)

Aulagnier, P. (1985). Os destinos do prazer (M. V. A. de Alencar, Trad.). São Paulo: Escuta. (Original publicado em 1979)

Aulagnier, P. (1990). Um intérprete em busca de sentido (R. Steffen, Trad.), vol. II. São Paulo: Escuta. (Original publicado em 1986)

\footnotetext{
${ }^{5}$ Esta pesquisa foi realizada num período em que a doação presumida ainda vigorava no país.
} 
Aulagnier, P. (Org.). (1991). Cuerpo, historia, interpretación. Buenos Aires: Libreria Paidós.

Bardin, L. (1979). Análise de conteúdo (L. A. Reto \& A. Pinheiro, Trads.). Lisboa: Edições 70. (Original publicado em 1977)

Baudrillard, J. (1970). La société de consommation. Paris: Gallimard.

Belk, R. W. (1992). Me and thee versus mine and thine: How perceptions of the body influence organ donation and transplantation. Em J. Shanteau \& R. J. Harris (Orgs.), Organ donation and transplantation: Psycbological and behavioral factors (pp. 139-149). Washington: American Psychological Association.

Bleichmar, H. (1985). O narcisismo (E. de O. Diehl \& P. F. Ledur, Trads.). Porto Alegre: Artes Médicas. (Original publicado em 1981)

Braidotti, R. (1987). Des organes sans corps. Em De la parenté - à l'engénisme (pp. 7-22). Paris: Les Cahiers du Grif.

Capisano, H. F. (1989). O corpo. Rio de Janeiro: Imago.

Certeau, M. de. (1996). A invenção do quotidiano (E. F. Alves, Trad.). Rio de Janeiro: Vozes. (Original publicado em 1990)

Corbin, A. (1990). O segredo do indivíduo. Em M. Perrot. (Org.), História da vida privada (cap. 4, pp. 419-501). (D. Bottman \& B. Joffily, Trads.). São Paulo: Companhia das Letras. (Original publicado em 1987)

Costa, J. F. (1986). Violência e psicanálise. Rio de Janeiro: Graal.

Grawitz, M. \& Pinto, R. (1967). Méthodes des Sciences Sociales. Paris: Dalloz.

Green, A. (1988). Narcisismo de vida, narcisismo de morte (C. Berliner, Trad.). São Paulo: Escuta. (Original publicado em 1982)

Green, A. (1995). La causalité psychique. Entre la nature et culture. Paris: Odille Jacob.

Hoelter, J. (1979). Multidimensional treatment of fear of death. Journal of Consulting and Clinical Psychology, 47, 996-999.

Jornal de Piracicaba (2000, 1 de Abril). Brasil pode ficar sem doadores. Jornal de Piracicaba, caderno $B, 4$.

Kent, R. \& Owens, R. G. (1995). Conflicting attitudes of corneal and organ donation: A study of nurses attitudes to organ donation. International Journal of Nursing Studies, 32(5), 484-492.

Kopfman, J. E. \& Smith, S. W. (1996). Understanding the audiences of a health communication campaign: A discriminant analysis of potential organ donors based on intent to donate. Journal of Applied Communication Research, 24(1), 33-49.

Kovács, M. J. (1985). Um estudo multidimensional sobre o medo da morte em estudantes das áreas de saúde, humanas e exatas. Dissertação de Mestrado não publicada. Instituto de Psicologia, Universidade de São Paulo, São Paulo, SP.

Kovács, M. J. (Org.). (1992). Morte e desenvolvimento bumano. São Paulo: Casa do Psicólogo Editora.
Le Breton, D. (1990). Anthropologie du corps et modernité. Paris: PUF.

Le Breton, D. (1995). Síndrome de Frankenstein. Em D. B. de Sant'Anna (Org.), Políticas do corpo (M. Moura, Trad.) (pp. 49-67). São Paulo: Estação Liberdade. (Original publicado em 1993)

Leclaire, S. (1992). O corpo erógeno (P. V. Vidal, Trad.). São Paulo: Escuta. (Original publicado em 1979)

Levin, J. (1987). Estatística aplicada a ciências humanas. São Paulo: Harba.

Moscovici, S. (1978). A representação social da psicanálise. Rio de Janeiro: Zahar.

Radecki, C. M. \& Jaccard, J. (1997). Psychological aspects of organ donation: A critical review and synthesis of individual and next-of-kin donation decisions. Health Psychology, 16(2), 183-195.

René, A. A., Vieira, E., Daniels, D.E. \& Santos, Y. (1994). Organ donation in the Hispanic population: Dondé estan ellos? Journal of the National Medical Association, 86(1), 13-36.

Riether, A. M. \& Mahler, E. (1995). Organ donation: Psychiatric, social and ethical considerations. Psychosomatics, 36(4), 336-343.

Sant'Anna, D. B. de. (1995a). Corpo e história. Cadernos de Subjetividade, 3, $243-$ 266.

Sant'Anna, D. B. de. (Org.). (1995b). Politicas do corpo. São Paulo: Estação Liberdade.

Scavone, L. (Org.). (1996). Tecnologias Reprodutivas. São Paulo: Editora Unesp.

Schilder, P. (1981). A imagem do corpo (R. Wertman, Trad.). São Paulo: Martins Fontes. (Original publicado em 1950)

Shepherd, R. S. \& Lefcourt, H. M. (1992). Death attitudes and humor: Taking a different perspective on organ donation. Em J. Shanteau \& R. J. Harris (Orgs.), Organ donation and transplantation: psychological and behavioral factors (pp. 50-58). Washington: American Psychological Association.

Shepherd, R. S. \& Lefcourt, H. M. (1995). Organ donation, authoritarianism and perspective-taking humor. Journal of Research in Personality, 29, 121138.

Souza Filho, E. A. de. (1995). Análise das representações sociais. Em M. J. Spink (Org.), O conbecimento no cotidiano (pp. 109-145). São Paulo: Brasiliense.

Spink, M. J. (1995). O estudo empírico das representações sociais. Em M. J. Spink (Org.), O conbecimento no cotidiano (pp. 85-108). São Paulo: Brasiliense.

Virilio, P. (1996). A arte do motor (P. R. Pires, Trad.). São Paulo: Estação Liberdade. (Original publicado em 1993)

Recebido em 4/09/2000

Revisado em 5/10/2000

Aceito em 1/11/2000

Sobre o autor:

Pedro Fernando Bendassolli é psicólogo, e estuda da Universidade Estadual Paulista, Assis. 